VŠB - Technical University of Ostrava, Institute of Geodesy and Mine Surveying

\title{
SINGLE-IMAGE PHOTOGRAMMETRIC METHOD OF VERTICAL WORKING-PRESENT SITUATION AND FUTURE OPTIONS
}

Summary. The goal of the presented contribution (paper) is to give an information on developments made by now and the present hardware and software equipment available for the single-image photogrammetric method of vertical alignment, straightness and profile measurements of shafts that have been developed in co-operation between the Institute of Geodesy and Mine Surveying of the VŠB -Technical University of Ostrava and the Scientific Research Institute of Mining at Radvanice. The method presented uses a photogrammetric equipment in two versions:

1. With plumb bobs for control points and one illuminating equipment which produces a planar light ray bunch, and

2. Without plumb bobs and with two light sources placed one above the other.

The equipment, including the photogrammetric chamber, is suspended below the cage. Images are evaluated by means of a monocomparator and special software developed by the Institutes mentioned above.

\section{ZASTOSOWANIE FOTOGRAMETRII JEDNOOBRAZOWEJ W POMIARACH INWENTARYZACYJNYCH SZYBÓW - STAN DZISIEJSZY I PERSPEKTYWY NA PRZYSZLO ŚĆ}

Streszczenie. W artykule autor przedstawił opis dwóch wariantów metody wykorzystującej technikę fotogrametrii jednoobrazowej do profilowania rur szybowych z klatek szybowych. Metoda ta opracowana przez Instytut Geodezji i Miernictwa Górniczego Politechniki w Ostrawie oraz przez Instytut G6rniczy w Ostrawie-Radvanicach wymaga zastosowania kamery fotogrametrycznej, którą wykonuje się zdjęcia na wybranych horyzontach obserwacyjnych poziomych przekrojów szybu utworzonych przez rzutnik światła realizujący na tych poziomach świetlne płaszczyzny horyzontalne. Różnica pomiędzy wariantami tej metody profilowania szybu sprowadza się przy tym do tego, że w pierwszym $z$. nich konieczne jest użycie dwóch lub czterech pionów opuszczonych w szybie, zaś w drugim - dwóch rzutników światła pozostających względem siebie i kamery fotogrametrycznej w stałej odległości.

Oprócz opisu technologii pomiarowej autor zaprezentowal również metodologię opracowania wyników takich pomiarów, w tym możliwości określenia różnych wielkości charakteryzujących deformacje szybu, co zostało zilustrowane właściwymi przykładami rezultatów takich obliczeń. 
Past decades have seen a development of numerous photogrammetric methods of mining surveying in Czechia which were applied in special cases in the practice of mining surveying. World-wide unique as it were, the development started back in the 1960s thanks to the researchers of the then existing Ore Research Institute of Praguc above all. They invented, built and manufactured a prototype of the illuminating equipment which produced the so called light datum and became the basis from which single-image photogrammetric methods for profile surveying of horizontal and vertical workings were developed.

There were several mining photogrammetric methods developed for very specific purposes (like the stereo-photogrammetric method to survey the caving vault for OKR) but were forgotten later. Any and all photogrammetric methods of mining surveying always raised a package of problems concerning illumination, procedure of measurement, and evaluation.

The widest range of application of single-image photogrammetric methods was offered by profile surveying of horizontal workings and by profile, vertical alignment and straightness surveying of vertical shafts-the so called (shaft diagnostics.( A lot of money and human effort has been spent on the latter since the early 1980 s by the University's Mining Surveying Base (MSB) in Ostrava and by the Scientific Research Institute of Mining (SRIM) at Ostrava Radvanice which still continues the developments in the field, mainly of the evaluation software.

The purpose of this paper is to offer a brief information on developments made by now and on present situation of the method in the context of the University and to present some thoughts on future options.

The University's Mining Surveying Base (MSB) Ostrava co-operated with SRIM Radvanice to work out a single-image photogrammetric surveying method for profile, vertical alignment and straightness surveying of shafts in two versions. One version uses plumb bobs for control points, the other doesn't. Both methods were tested and applied especially in OKR mines. Each version has virtues and vices. Both use the same flash illuminating equipment which produces a light ray bunch datum. 


\section{Single-Image Photogrammetric Method of Shaft Profile, Vertical Alignment and Straightness Surveying with Plumbing Bobs}

\section{Description of Apparatus:}

The photogrammetric chamber hangs down from the bottom of the cage, its axis being vertical. The set currently used by the VŠB - Technical Univerity of Ostrava has an AFP 21 Soviet-made aerial photogrammetric chamber producing $13 \times 18 \mathrm{~cm}$ images. A flash light lamp is suspended at a suitable distance below the photogrammetric chamber to radiate a horizontal planar ray bunch which marks a thin light trace (4-5cm thick, depending on shaft diameter) on the lining, outfit and other equipment found in the shaft. A pantographic system of suspension wires keeps the light datum horizontal even if the equipment tends to swing. The set is operated out of the cage. Images are usually taken at regular horizontal steps of $5-10 \mathrm{~m}$ as the customer wishes. The steps can be adjusted as may be needed (like to skip a water curtain, shaft landing. etc.).

\section{Plumb Bobs:}

To evaluate vertical alignment and straightness of shaft lining and, primarily, of cage guides, at least two plumb bobs must be suspended along the space under measurement Narrow strips of plumb bobs are illuminated by the light datum which serve as control points for the evaluation. The real plumb bob distance can be used to calculate image scale. To identify pro-file point positions a co-ordinate system based on the plumb bob connecting line is used. The co-ordinate system is common for all profiles. Vulnerable to falling drops of water and mine air, plumb bob suspension and arresting in strictly vertical position causes considerable problems and multiplies the time needed for taking the measurements while the shaft must stand still. Instead of plumb bobs, existing vertical equipment of the shaft is often used (signal wires, etc.), but there is no guarantec to its vertical alignment. In some cases there is only one such control element which does not allow shaft profile twist measurement. If the element is not reasonably vertical but is fairly stable (bottom and top arrested, tensioned steel wire), then distances of measured points in the shaft (e.g. cage guides) from this element can be taken for straightness parameters, not for vertical alignment parameters. Straightness is critical ofor shaft function. Another important factor for the function is cage guide distance which can also be checked using this method. 


\section{Measurement Project:}

Reconnaissance of shaft must precede the measurement and a project must be prepared. The scope of project must include:

1. Job organisation. Permit to use open fire must be obtained if there is impending danger of methane explosion. Time needed to put the shaft out of operation must be assessed.

2. As detailed data as possible must be obtained on shaft profile, lining and outfit along the shaft's length plus compartments for the measurement and points for plumb bob suspension must be selected or a suitable element must be chosen for control point.

3. Minimum camera-to-lighting equipment distance (length of suspensions) must be determined for the image to show the whole shaft profile, and photo chamber must be positioned within the shaft profile.

4. Profile-to profile step.

5. Selection of suitable shaft elements to measure real distance at selected profiles to calculate image scale.

6. Fastening of photogrammetric chamber to and suspensions of light source on the cage. Installation place and method, set adjustment.

7. Illumination set depth below indication datum (i.e. below an outfit element of known position to be used as profile reference point.)

8. Cage travel method, either stepwise-stop and shoot at each level-or slow continuous motion with shot taking at moments of passing of selected outfit elements, see par. 7.

9. Signals and communication with cage operator during the making of measurements.

10. Sequence of repeated actions during measurement, recording method for data needed to identify individual images and their respective shaft positions.

11. Choosing top-down or bottom-up procedure.

Once the preparation, installation, rectification and function tests of the equipment have been done, the measurement itself is usually very fast to carry out. A $700 \mathrm{~m}$ deep shaft takes 30-60 minutes to be measured.

\section{Evaluation of Photogrammetric Images:}

Each shot of the exposed film must be identified according to data entered in the measurement protocol. Evaluation basis are the co-ordinates derived from images by means of the ASCORECORD monocomparator. Control point (plumb bob) and measured point (cage guide edges, points on circumferential lining of the shaft) co-ordinates are read from the images using the monocomparator's own co-ordinate system. The multiple amplification of 
the monocomparator's microscope led to the development of special software by the MSB to search and find the points in the image. As a rule, 16-24 points are picked up to survey the shaft lining, at regular distances from one another if possible. This makes it possible to evaluate radial displacement of any point of lining from its ideal position plus to locate the shaft profile centrepoint (so call-ed shaft target.) In addition, shaft lining radii is calculated in round shafts as an average of three radiuses pertaining to three selected points of the lining.

Based on the known control point co-ordinates, the monocomparator co-ordinates are transformed into the common co-ordinate system used for all profiles. The system is then used to evaluate cage guide, shaft lining and profile centre (shaft axis) displacements from the plum bob vertical. If a straight but not strictly vertical shaft element is used (e.g. tensioned wire) the calculated data indicate straightness deviations of the shaft.

To evaluate vertical displacements, two vertical planes perpendicular to each other are used, usually running through the starting profile (topmost or bottom-most) cage guide connect-ing lines. The VŠB - technical University of Ostrava made special software makes both calculated numerical outputs and graphic outputs possible (see annexes.) A 3D diagram of the connecting line be-tween selected measured point (e.g. cage guides) can also be part of the graphic output.

\section{Single-Image Photogrammetric Method of Shaft Profile, Vertical Alignment and Straightness Surveying without Plumbing Bobs}

Inspired by problems incurred by plumb bob manipulation in the shaft, a single-image photogrammetric method authored by Blahoslav Fojth, researcher at SRIM Radvanice, had been developed since the early 1980s. The method's principle is based on the use of two planar ray bunches at a time. One image then shows two shaft profiles at a pre-set, constant distance from each other (one step apart.) Images are shot stepwise while the apparatus (suspended below the cage) moves exactly by one step each time. If the co-ordinates of chosen points of the starting profile (so called transfer points; at least two, usually 4 or more) related to its own co-ordinate system applicable to all profiles are known, the co-ordinates can bc transferred from profile to profile along the whole length of shaft section monitored. The necessary condition is exact step-ping so that the lower profile of any following image is identical with the upper profile shown on the corresponding preceding image (in bottom-up 
procedure), or that the upper profile of any following image is identical with the lower profile shown on the corresponding preceding image (in top-down procedure.)

To guarantee the moving of cage exactly by one step each time, a perfect system of communication with the cage operator must be provided and the operator needs a special cage position indicator made for the purpose.

The profile step thus must be exactly uniform along the measured shaft section which may cause problems in places where the transfer point sequence is disrupted (e.g. cage guides at landings) and suitable substitute points must be found. The measured point sequence must not be disrupted because the profile-to-profile transfer would not be possible otherwise.

The evaluation procedure is similar to the previous method. Monocomparator co-ordinatc readings are followed by transfer point (cage guide edge) relative position calculations and by comparisons thereof with the corresponding positions of the preceding image. A point of excessive image-to-image position difference must be excluded.

Special software has been developed by VŠB - Technical Ostrava to calculate the transformation equations. Like in the previous method, there are numerical and graphic outputs showing dislocation of measured points from the vertical.

The advantage of this method is the elimination of plumb bobs while there are high requirements on measuring set parameter precision, especially exact step-by-step movement of cage, exact transfer point position identification and the critical importance of uninterrupted sequence of measurements along the whole measured length.

\section{Application of the Single-Image Photogrammetric Method to Large-Diameter Bore Hole Profiles}

Large bore holes are important parts of mine air or transport systems in underground mines. There may be need to inspect the otherwise inaccessible vertical workings for security reasons, especially in cases of wall stability disturbance or cavitation.

The single-image photogrammetric method makes it possible to survey selected bore hole sections, helps to work out maintenance procedures and to take measures in order to makc further function of the bore hole safe. There are usually no requirements on alignment or straightness measurements; depth and shape of surveyed profile are sufficient outputs. Consisting of a camera and illumination equipment at a fixed distance from each other, the 
surveying set is thus lowered into the bore hole and a series of profile images are made at a chosen pace. To orient the images a wire can be suspended along with the set.

\section{Future Options}

The methods and equipment described above were put in operation by the Mining Surveying Base ofVŠB - Technical University of Ostrava and SRIM Radvanice in 1985. Many successful measurements were made for OKR shafts and the method proved viable under various conditions. There was a drop in demand for such measurements caused by the mining recession which causes temporary (as we are hoping) problems concerning the funding of further development of the methods. The envisaged development could follow the listed principles:

1. The apparatus and surveying method must be adapted to use during slow, continuous lower-ing or lifting of the cage without stopping. To achieve this a suitable exact-timing camera and light triggering pulse source must be tcsted. Visual orientation and manual exposure to shoot lining elements being passed by is distorted by a considerable personal error and is not reasonably exact and, is in fact, useless especially for the method without plumb bobs.

The following solutions can be taken into consideration:

a) The pulses can be generated by a calibrated wheel rolling along the cage guide. The method has already been tested but showed problems caused by slipping of the wheel on the greased cage guide.

b) The pulses can be generated by a drum suspended below the cage from which a wire is unwinding while the cage is moving.

c) The pulses can be generated by points (nails) driven into cage guides from the side so that they do not interfere with the cage which will activate the apparatus trigger. This method enhances requirements on preparatory work but is advantageous for shafts' where repeated measurements are planned. The advantage here is the exact known location of each profile and exact profile-to-profile distances.

2. A direct continuous cage guide distance surveying equipment will be added to the surveying set because guide distance is the most important shaft operation safety factor to be monitored. Direct guide distance measurement is an important precision improving element in photogrammetric image evaluation. Such additional equipment has been tested by OKR and in 
Poland, but a suitable continuous registration equipment to record measured guide distance data with corresponding depths is not available as yet.

3. There is a theoretical option of computerised processing of photogrammetric images scanned nto a high-resolution computer, but VŠB - Technicaů University of Ostrava does not have a suitable equipment for the purpose.

4. A very distant vision is to use a CCD camera directly in the shaft to make images. This would enable electronic processing of images and offer a solution to increasing problems with the acquisition of special high-sensitivity negative material.

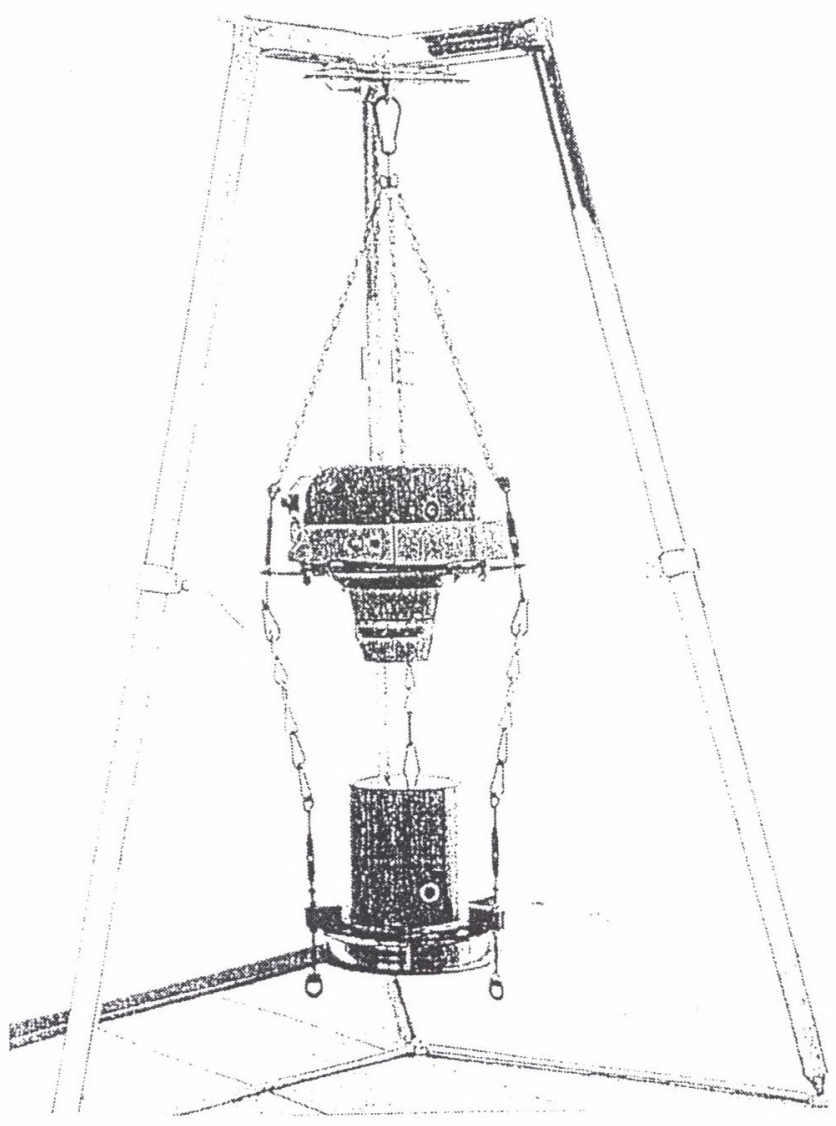

Fig. 1. Photogrammetric method using one illuminating source hanging on a short suspension

Rys.1. Fotogrametryczne oprzyrządowanie $\mathrm{z}$ wykorzystaniem jednego ḱródła światła wiszącego na krótkim zawiesiu 


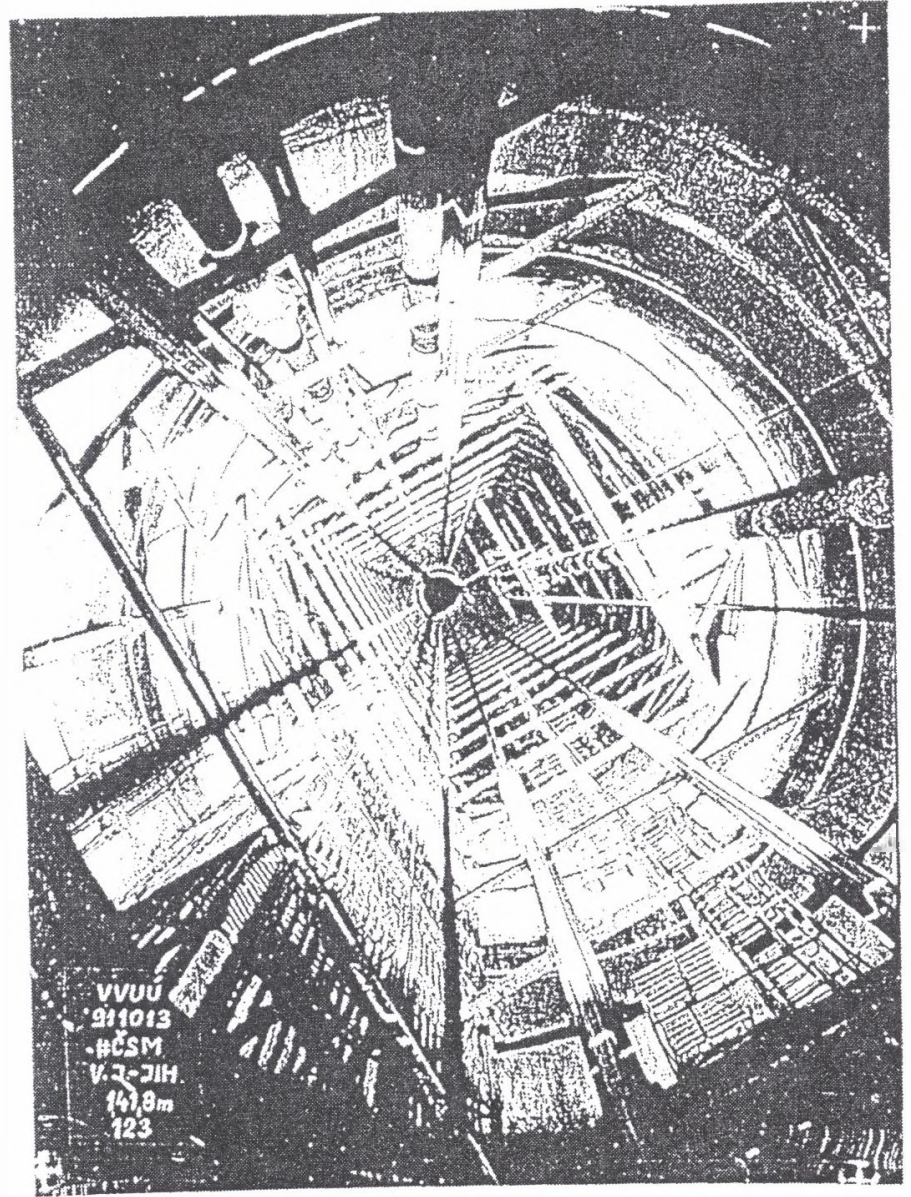

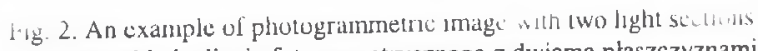

Rys.2. Przykład zdjęcia fotogrametryczncgo z dwiema płaszczyznami świetlnymi 


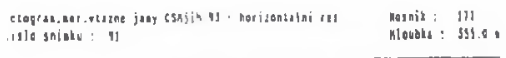
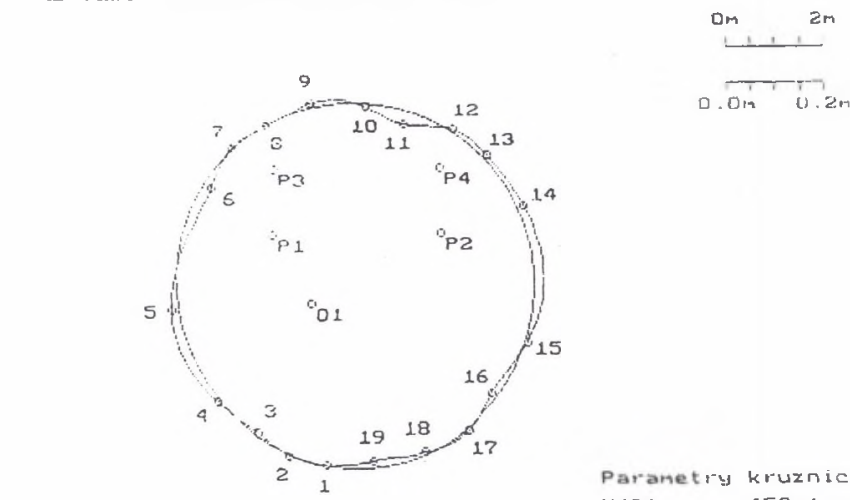

Paranetry kruznice x(S): $\quad-459.1 \mathrm{~mm}$ Y(S): $\quad-958.5 \mathrm{~mm}$

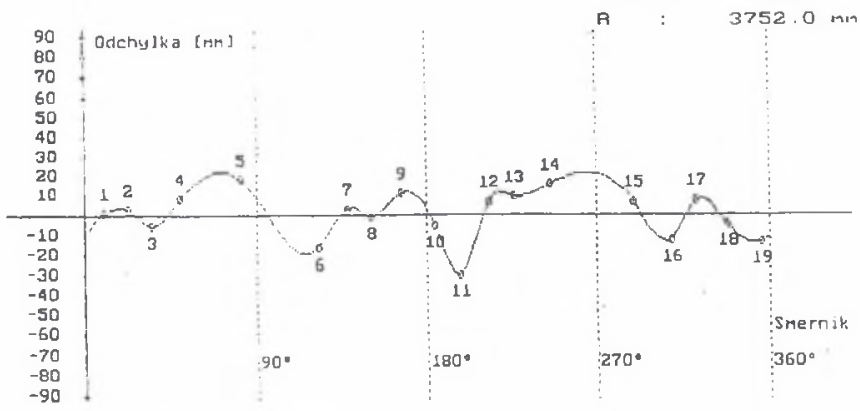

\begin{tabular}{|c|c|c|c|c|c|c|c|c|}
\hline Ior & Suetuik & Ddehriys & Bed & Sutinjt & Odehyilh & Iod & Satrnik & 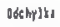 \\
\hline 1 & $10^{\circ}$ & 1911 & $s$ & $\mid b \mathbf{b}^{\prime}$ & $10.6 \mathrm{MI}$ & II & $s 2 z^{\prime}$ & ב \\
\hline$i$ & $z^{*}$ & 2.611 & 10 & $18 d^{\prime}$ & -5.1 al & II & gy' & $-0.1 \mathrm{u}$ \\
\hline j & is' & $-5.4 \|$ & 11 & $19{ }^{\circ}$ & $29.6 \mathrm{an}$ & 11 & 355' & " ו 1,1. \\
\hline I & $50^{\circ}$ & $1.1 \mathrm{II}$ & na & 2.4 & I. I II & & & \\
\hline s & iz & 11.11 & 13 & 217 & $9 . J$ ॥ & & & \\
\hline ? & $12 \mathrm{~J}^{\prime}$ & $-15.9 \mathrm{at}$ & iv & $246^{\prime}$ & $15.6=$ & & & \\
\hline 7 & I $5 \mathrm{~s}^{\prime}$ & $3.1 \mathrm{~m}$ & 13 & $2 \% 9^{\circ}$ & 1018 & & & \\
\hline 1 & 's1' & -010 & II & $301^{\prime}$ & -12.211 & & & \\
\hline
\end{tabular}

Fig. 3. Round shaft profile distortion evaluation

Rys.3. Wykres deformacji w poziomym przekroju szybu 


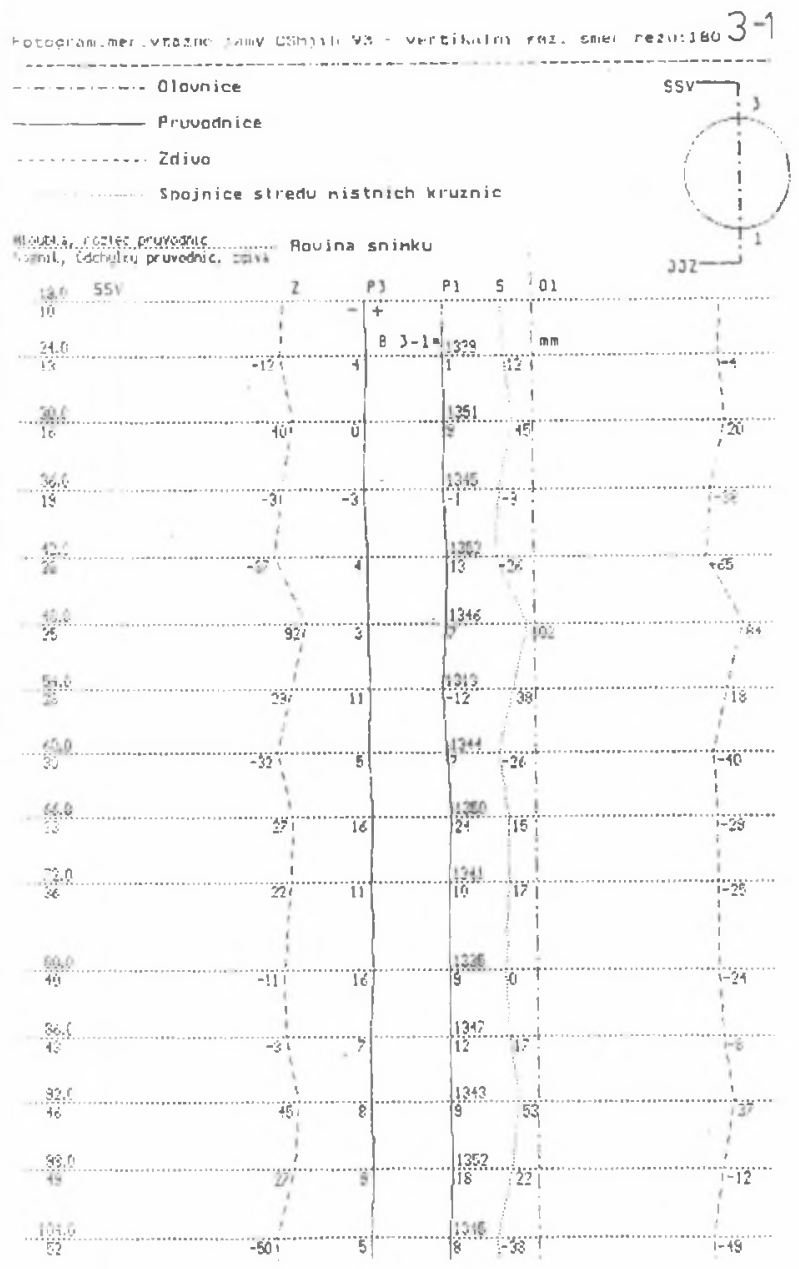

Fig. 4. Vertical section view showing deviations of plumb bob, cage guides, lining and shatt centreline from the vertical

Rys.4. Przekrój pionowy przedstawiający położenie pionów, prowadnic szybowych, oḅudowy szybu i środka szybu w płaszczyźnie pionowej 


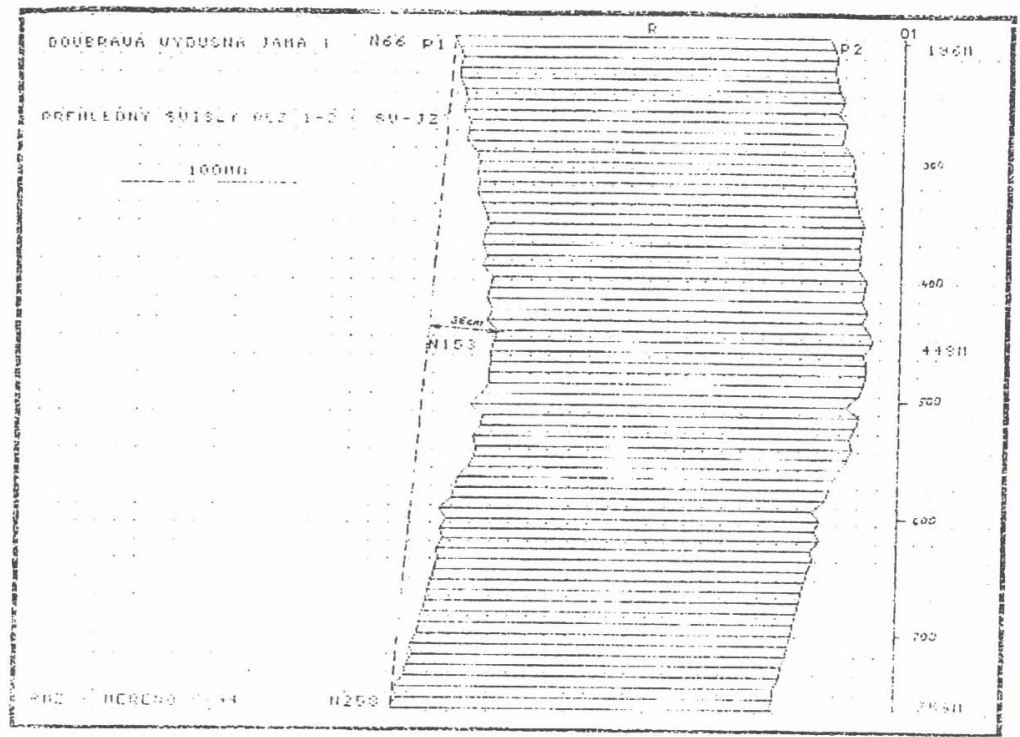

Fig.5. Vertical section view showing deviations of shaft Rys.5. Przekrój pionowy szybu przedstawiający jego deformacje

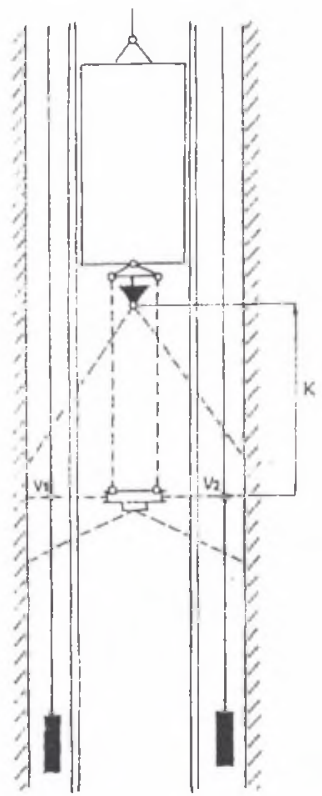

Fig.6. Single-Image Photogrammetric Method of Shaft Profile, Vertical Alignment and Straightness Surveying with Plumbing Bobs

Rys.6. Metoda fotogrametrii jednoobrazowej dla profilowania szybu, oceny jego pionowości i prostoliniowości z wykorzystaniem swobodnic zwisających pionów 


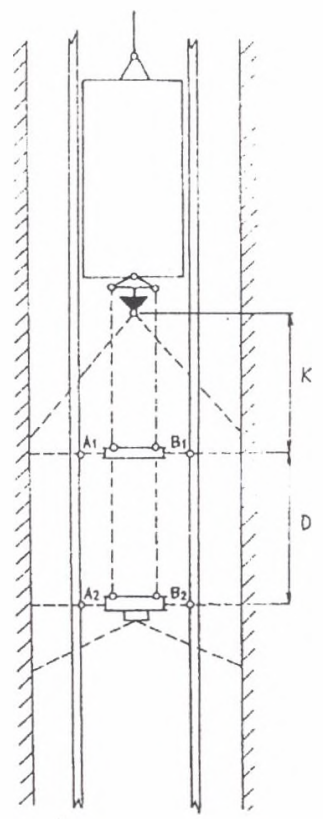

Fig.7. Single-Image Photogrammetric Mcthod of Shaft Profile, Vertical Alignment and Straightncss Survcying without Plumbing Bobs

Rys.7. Metoda fotogrametrii jednoobrazowej dla profilowania szybu, oceny jego pionowości i prostoliniowości hez użycia swobodnie zwisających pionów

\section{Conclusions}

Photogrammetric methods described and corresponding apparatus are functional and available at VŠB - Technical University of Ostrava and SRIM Radvanice. Their applicability to various shaft types and sizes has been proved by numerous field measurements.

\section{REFERENCES}

1. Černy I., Mikulenka V., Kičmer M.: Zjiš̃'ování stavu velkoprůmêrových vrtŭ fotogrammetrickou metodou, Ostrava 1988

2. Čemý I., Mikulenka V., Kičmer M.: Vývoj a ově̌ení fotogrammetrické soupravy, měrických postupů a metod vyhodnocováni pro měření deformací výztuže jam o velkém průmèru, Ostrava 1988 
3. Cerný I., Mikulenka V., Kičmer M.: Závễrečná zpráva úkolu „Zaměřování deformací důlních jam" Ostrava 1990

4. Cerný I., Vojtovič V., Kičmer M.: Fotogrammetrické zaměřování přímosti a svislosti prûvodnic výdušné jámy č. 1 Dolu Doubrava, Technická zpráva, VŚB - TU Ostrava 1994

5. Fojtů B., Mikulenka V., Slivečka : Fotogrammetrické zaměřeni svislosti vybraných jam dolu J. Fučík, Ostrava 1992, 1993

Recenzent: Dr hab.inż. Jan Białek

Prof. Politechniki Śląskiej

\section{Abstract}

Single-image photogrammetric method, a profile of a vertical shaft is lit by a narrow beam of light and then an image of the profile is taken with a photogrammetric camera. The photogrammetric camera is suspended from a cage (skip), its axis being vertical. A lighting installation is suspended at a predetermined constant distance. Images can be taken either when the cage is stopped at a wanted level or when the cage slowly and continually moves while the camera and the lighting installation are automatically switched on when they reach indicatory levels (e.g. selected elements of the shaft support).

To evaluate the shape of a lit shaft profile, a lining alignment and most importantly a shaft guide alignment and straightness, a comparison of relative positions of individual surveyed profiles needs to be made. By this reason, the VŠB - Technical University of Ostrava and the VVUÚ (Scientific Research Institute of Mining) of Radvanice developed together two versions of the above-mentioned photogrammetric method:

\section{a) The first version uses plumb bobs as control points for all surveyed profiles}

This version uses at least two (but usually four) plumb bobs which are suspended along the whole space under measurement. They serve as control points common to all surveyed profiles. The relative position of the plumb bobs is measured near their suspensions so that the plumb bobs form a pattern that is invariable for all profiles after their swinging has ceased. 
The intersection of a plane horizontal light beam and a plumb bob suspension and each profile are lit simultaneously. The intersection forms a clear bright point on the image.

The suspension of the lighting installation is constructed in the way that the horizontality of the plane beam of light is maintained even during contingent swinging of the suspension. The lenght of the suspension is adjusted to the projection angles of the photogrammetric camera, to the diameter of the shaft and to the position of the set in the shaft profile in the way that the whole profile can be seen on the image. The lenght of the suspension is unchangeable for the given shaft and the scale of all images remains the same. The Ascorecord monocomparator reads the image coordinates of intersections of the plane light beam with plumb bobs (control points), and of all the other observed points (cage guide edges, points on a shaft lining, etc.) The image coordinates are then transformed into a coordinate system common to all surveyed profiles.

The position of observed points in relation to the vertical is evaluated (plotted) both numerically and graphically on two vertical planes perpendicular to each other. Consequently, one becomes acquainted with verticality (straightness) of shaft guides, shaft lining and shaft axis.

The relative accuracy of evaluated (plotted) positions of observed points in a given profile in relation to position of plumb bobs is very good $(1-3 \mathrm{~mm})$ and depends mainly on unambiguousness (sharpness) of an image.

The accuracy of relative positions of profiles depends on the accuracy of plumb bob positions on the vertical. Any swinging or oscillation of plumb bobs may damage required data. By those reasons and by reason of difficult plumb bob handling, the use of plumb bobs is not suitable for depths of more than 200 to 300 metres.

b) The second version does not use plumb bobs while two profiles are lit at the same time and at a constant distance.

The version which does not use plumb bobs utilizes two sources of plane beams of light (authored by ing. Blahoslav Fojtů) which are suspended from the camera at constant distance from each other. Consequently, images show two lit profiles simultaneously, each of them being at different distance from the camera, and so in different scale. If one of the profiles on the image contains points of which we have measured the relative position directly, it is possible to determine the position of points in the plane of the second profile by transformation of the measured image coordinates of selected points of both profiles. If the next image is taken after travel of the whole set (the travel distance being the distance of the 
light planes), the profile which has been determined becomes the reference profile. The whole cycle is repeated. It does not matter whether one moves from the bottom upward or from the top downward. Should this method be successful it is necessary for the travel distances to bc exactly the same as the distance of both light planes. Selected points (called transfer points) which are unambiguous and bright on an image, and guarantec the most reliable "transfer" of the relative position from one profile to another are used for solutions of transformation equations. 